\title{
The Position of Clitics in Phrases with an Infinite Verb Form in Romance Languages
}

It is generally held that the original Indo-European word-order is $\mathrm{SOV}^{1}$, but this changed over time, and SVO is now a common feature of Indo-European languages. J.H. Greenberg argued that "if in a language the verb follows both the nominal subject and the nominal object as the dominant order, the language almost always has a case system." 2 W. P. Lehman and others have long argued that prepositions have been introduced later to a $\mathrm{VO}+$ postposition system, thus undermining the case system by making the SVO order necessary to differentiate nominal subject from nominal object. ${ }^{3}$ However, some linguists have suggested that in Proto-Indo-European there also existed prepositions and therefore the SVO possibility as well. ${ }^{4} \mathrm{~J}$. A. Hawkins has also stressed "that the existence of VO \& + Case languages, such as Lithuanian, means that the loss of the case system is not a necessary cause of the OV to VO shift, since OV can shift to VO whether or not the case system is eroded, but it is certainly a sufficient cause." 5

1 = Subject + Object + Verb

2 J.H. Greenberg, "Some universals of grammar with particular reference to the order of meaningful elements." In: Universals of Language, ed. by J.H. Greenberg, MIT Press, Cambridge, Mass, 1966, p. 96.

3 W.P. Lehman, Proto-Indo-European Syntax, University of Texas Press, Austin, 1974.

4 J.A. Hawkins, Word-order Universals, Academic Press, New York, 1983, chapter 7. - , "Seeking Motives for Change." In Studies in Typology and Diachrony: For Joseph H. Greenberg, ed. by W. Croft, K. Denning and S. Kremmer, John Benjamin Publishing Company, Amsterdam/Philadelphia, 1990, pp. 95-128.

5 op. cit. p. 102.

* Ingmar Söhrman

S-Umeå University 
Modern Romance languages all have the SVO order but for clauses where clitics substitute nouns.

Especially in Europe the SVO order is sometimes considered to be "the logical order". 6 Latin being a case system language was mostly a SOV language, although word-order was fairly free due to the existing case system (1a and 1b). ${ }^{7}$ In example (1a) we find both a noun and a clitic in the position of a direct object.

(1a) Quis est homo qui timet dominum docebit eum in via quam elegit. (Psalter 25:12)

(1b) Helvetii Germanos aut suis finibus prohibent aut ipsi in eorum finibus bellum gerunt.

The mere existence of the SVO possibility in Latin, even if it was the less used one, explains why the shift was so easily made and perhaps also why there is still a remnant of the old SOV system in Romance languages. Given that both word-orders coexisted the system change represented a change of preference in the predominant word-order rather than a total system shift.

Where there is a full noun object the normal modern Romance wordorder is SVO (2a and 2b). Topicalization changes this, although this anaphoric process lifts out one element of the standard composition of the phrase, and this has to be substituted by a clitic ( $2 \mathrm{c}$ and $2 \mathrm{~d}$ ).

(2a) Carmen compró el vestido en El Corte Inglés. (S) 8

(2b) Non fanno vedere $i$ quadri a nessuno. (I)

(2c) El vestido, Carmen lo compró en El Corte Inglés. (S)

(2d) I quadri non li fanno vedere a nessuno. (I)

In this article I use the denomination clitic for a complementary pronoun without any inherent accent, although I will discuss a few examples where the clitics in the given sense have been substituted by

\footnotetext{
6 G. Ineichen, Allgemeine Sprachtypologie. Darmstadt, 1991, p. 132.

7 H. Rubenbauer, J.B. Hofmann, Lateinische Grammatik, neubearbeitet von R. Heine, Bamberg, München, 1995, p. 325.

8 In order to facilitate the lecture I will give the following abbreviations for different languages from which $\mathrm{I}$ have taken examples: $\mathrm{A}=$ Asturian, $\mathrm{C}=$ Catalan, $\mathrm{F}=$ French, $\mathrm{Fr}=$ Friulian, $\mathrm{G}=$ Galician, $\mathrm{I}=$ Italian, $\mathrm{O}=$ Occitan, $\mathrm{P}=$ Portuguese, $\mathrm{RR}=$ RhaetoRomance or Romansh (if not mentioned otherwise in the text, all RR examples are Sursilvan), $\mathrm{R}=$ Romanian, $\mathrm{Sa}=$ Sardinian, $\mathrm{S}=$ Spanish, $\mathrm{Ge}=$ German and $\mathrm{Sw}=$ Swedish.
} 
stressed forms like in (3a). ${ }^{9}$ Reflexives are, of course, also clitics and are thereby included in this discussion. However, I will not discuss clitic doubling $(3 b)$ or configurations with non-clitic reflexives where no clitic doubling is required $(3 \mathrm{c}) .{ }^{10}$

(3a) Donne-le-moi. (F)

(3b) Je te le donne à toi. $(\mathrm{F})$

(3c) Maria guarda se stessa. (I)

Afirmative imperative forms are always constructed with enclitic pronouns - clitics or not ( $3 a$ and $4 a$ ). In some vernaculars the enclisis is still found in spoken language such as in the Carribean, Chile and some other parts of Latin America (4b), where the plural ending is repeated after the clitic or because of a metathesis at the end of the finite verb after the enclitic pronoun. ${ }^{11}$ In literary and administrative language there also exists a possibility of enclitic usage after past participles (4c and $4 d$ ) in some Romance languages. ${ }^{12}$

(4a) Dateglieli. (I)

(4b) Siéntensen; delen. [in standard Spanish = Siéntense; Denle] $(\mathrm{S})$

(4c) La risposta negativa datami da lei. (I)

(4d) Algún angel había descendido a mí y consoládome durante mi sueño. ( $S$, Pérez Galdós)

It would seem reasonable to believe that Galician and Portuguese would admit the enclisis after a past participle, since the enclisis is the rule in afirmative clauses in these languages, but this is not at all the case. The enclisis is totally excluded in combination with a past parti-

9 The complications of finding a definition that completely covers the notion of clitic is described in an article by L. Fant, "El pronombre clítico en las lenguas iberorómanicas y en otros idiomas. Aspectos sobre una cuestión de tipología lingüística." $C E B A L$ (Copenhagen School of Economics and Business Administration, Language Department Series), nº 7, Copenhagen, 1985, pp. 29-62.

10 E. Torrego, "From argumental to non-argumental pronouns: Spanish doubled reflexives", Probus, 7, 1995, pp. 221-241. See also R. Kayne, French Syntax: The Transformational Cycle, Cambridge, MA., 1975.

11 M. Vaquero de Ramírez, El español de América, II, Morfosintaxis y Léxico, Madrid, 1996 , p. 22.

12 C. Schwarze Grammatik der italienischen Sprache, 2nd ed., Tübingen, 1995, p. 216; E. Alarcos Llorach, Gramática de la lengua española, Madrid 1994, p. 148-149. 
ciple (5a). ${ }^{13}$ This is also the case in clauses where the present participle is allocated to the left (5b).

(5a) Desa maneira non o dás pillado nunca. $(\mathrm{G})$

(5b) Ben amolado che estou. (G)

When an object noun phrase is substituted by a clitic, the Romance standard order is SCV, where C stands for Clitic (6a and 6b). This order is equivalent to the original SOV. In medieval Romance texts both SCV an SVC are found (6c-f). The enclisis was the standard position in medieval Spanish, but uncertainty already appeared in the 16th century as can be seen in Cervantes' certificate of baptism (6g). Even today the enclisis is, of course, not entirely unusal in poetry and archaic language.

(6a) Je t'aime. (F)

(6b) Ti amo. (I)

(6c) [...] ge le vos enseignerai bien (F, Mort Artu 87,33)

(6d) Falt me li cuer. (F, Eneas 1274)

(6e) E conpóselo otrosí a dar algunos leçon [...] (S, Libro de buen amor, 135)

(6f) Quand'eo li parlo, moroli davanti [=le muoio] (I, Iacopo da Lentini) ${ }^{14}$

(6g) [...]; fueron sus compadres Juan Pardo, baptizóle el reverendo Señor Bachiller Serrano Cura de Nuestra Señora, testigos Baltasar Vázquez Sacristán, é yo que le bapticé é firmé de mi nombre Bachiller Serrano. (S) ${ }^{15}$

Pronouns are bound variables, i.e. they belong to a closed class category and are therefore restricted as to number and function, while most objects are nouns which represent an open class category. They can thus be seen as free variables, since there are no theoretical limits to this class. It seems fair to believe that clitics with their very restricted number should belong to basics in a language, and that they therefore could be expected to remain faithful to the original word-order. It should also be remembered that the infinitive that originally was a verbal noun in

13 R. Alvarez, X.L. Regueira \& H. Monteagudo, Gramática Galega, Vigo, 1986, pp. 203-204.

14 A Sicilian poet from the XIIIth century. L. Serriani, Grammatica italiana, Italiano comune e lingua letteraria, Torino, 1989, p. 260.

15 Quotation from Libro Sacramental Parroquia de Santa María de Mayor 1547, Alcalá de Henares. 
Latin in most Romance languages has extended its verbal functions and now become the canonical verbal form. ${ }^{16} \mathrm{R}$. Posner draws a reasonable conclusion that well supports the argument of this article.

"In resultant finite verb + infinitive sequences, where two verbs share the same subject, a clitic pronoun object of the infinitive often attaches clitically to the (higher) finite verb"17

Another factor that also ought to be taken into consideration is that it seems just to believe that structural basics resist changes longer as E. Sapir once pointed out:

"Languages are in constant process of change, but it is only reasonable to suppose that they tend to preserve longest what is most fundamental in their structure." 18

In Romance languages clitic climbing is an old pattern that is spreading. This phenomenon has in some countries been seen as bad language and therefore ousted.

"One assumes that there was considerable cohesion between the sequential verbs, so that they filled a single verb slot. The climbing pattern seems sporadically to have spread by analogy to other finite verb + infinitive sequences, even where the infinitive is introduced by a preposition (or complementizer). However, in the modern period there has been some reaction against climbing, with a tendency prompted by logical and semantic considerations, to cliticize the object pronouns to the verb to which it most closely relates. This process is most advanced in French, where climbing with modals is no longer permitted in the standard, following the intervention of the language arbiters." 19

However, Romansh is the Romance language that stands out, possibly due to German influence (7a) ${ }^{20}$, since Germanic word-order is SVC as can be seen in ( $7 b$ and $7 c)$. The Sursilvan does not even have clitics. There are only full objective forms to be used. Engadine dialects hold to the Romance pattern as can be seen in the Vallader (Lower Engadine)

16 R. Posner, The Romance Languages, Cambridge University Press, Cambridge, 1996, p. 163.

17 Op. cit., p. 263.

18 E. Sapir, Language. An Introduction to the Study of Speech, New York, 1921, p. 144.

19 R. Posner, op. cit., p. 266.

20 I. Söhrman, ”Deutsche Einflüsse auf das Rätoromanische”. In M. Todtenhaupt \& I. Valfridsson, Sprache als lebendige Kulturspiegel, Acta Universitatis Umensis, Umeå Studies in Humanities, 119, Umeå, 1995, pp. 195-202. 
example (7d). The central dialect, Surmiran, mostly follows the Sursilvan pattern (7e), although the clitic possibility still exists but is now restricted to literary usage $(7 \mathrm{f}) .{ }^{21}$

(7a) El scriva a ti. (RR)

(7b) Er schreibt dir. (Ge)

(7c) He writes to you.

(7d) El at scriva. (RR)

(7e) El screiva a tè. (RR)

(7f) El at screiva. (RR)

Portuguese does at a first glance resemble Romansh since the regular word-order is SVC ( $8 \mathrm{a}$ and $8 \mathrm{~b}$ ). The difference is that in Portuguese the pronouns are clitics and they are clearly enclitically linked to the finite verb (8a and 8b), even prosodically and not just orthographically with a hyphen. This word-order is also found in Galician and Asturian (8c). However, in Portugese, Galician and Asturian this SVC order is substituted by SCV in a question, a negated clause (8d), after certain adverbs and in a subordinated phrase introduced by the general conjunction que. ${ }^{22 / 23}$ These contrasting word-orders can be seen in (8e). Since this enclitic pronoun can never be stressed, it is a completely different case from the Romansh SVC order. It would seem reasonable to regard this $\mathbf{S V + C}$ in order to point out the close relation between the finite verb and the clitic. This might be seen as a variety of the SCV order in the sense that the clitic is linked to the finite verb although by enclisis. The $+\mathrm{C}$ is a way of denoting the enclisis. As the proclitic word-order is compulsory in many instances of affirmative main clauses European Portuguese does not provide a real counterexample to the SCV order being the general Romance word-order. In Brazilian Portuguese clitics are always proclitic (8f), and, as we have just seen, in certain clauses proclisis is the rule also in European Portuguese. ${ }^{24}$ In the Sursilvan

21 A. Spescha, Grammatica sursilvana, Chur, 1989, pp. 334-336; G.P. Ganzoni, Grammatica ladina, Samedan, 1983, pp. 62-67: G.P. Thöni, Rumantsch surmeir, Chur, 1969, pp. 74-75.

22 H. Krenn \& M.A. Soares de Carvalho Mendes, Modernes Portugisisch, Tübingen 1987, pp. 121-122 and 149.

23 H. Krenn \& M.A. Soares de Carvalho Mendes, op. cit., pp. 183-199, and R. D’Andrés Díaz, Allugamientu de los pronomes átonos col verbu n'asturianu, Oviedo, 1993, pp. 44-48.

24 H. Krenn \& M.A. Soares de Carvalho Mendes, op. cit., p. 122. 
(Romansh) case as in Germanic languages the postverbal non-clitic pronoun can be both stressed and separated from the finite verb by a negation or adverbial complement $(8 \mathrm{~g})$. As we have already seen this is not the case in Engadine dialects (8h). Nevertheless, in colloquial Brazilian Portuguese there is a clear preference for full forms, and clitics are mostly avoided. ${ }^{25}$ The standard word-order in Brazilian Portuguese is still the proclisis (8f).

(8a) Trata-se dum negócio importante. (P)

(8b) Chamo-me Henrique. (P)

(8c) Não te preocupes. (P)

(8d) Díxolo. (A)

(8e) Pensa-se que não ano de 1969 se realizará a primeira viagem à lua. (P)

(8f) Me chamo Maria. (P)

(8g) El scriva buca [=not] a ti. (RR)

(8h) El nu't scriva. (RR)

The SCV word-order is also valid for compound tenses (9a and 9b) in all the Romance languages with the exception of some Romansh dialects that go an entirely different way, as we have already seen. Another minor exception is the third person singular feminine in Romanian, which is always positioned after the participle (9c). However, loro (as indirect object) in Italian is unique as it can be interposed between auxiliary and participle (9d), although the postposition is much more frequent $(9 \mathrm{e})$. On the other hand this pronoun is not a clitic. ${ }^{26}$

(9a) Gabriella l'ha scritta. (I)

(9b) Gabrielle l'a écrite. (F)

(9c) Gabriela a scris-o. (R)

(9d) Gabriella ha loro scritto. (I)

(9e) Gabriella ha scritto loro. (I)

Affirmative imperatives always use the $\mathrm{VO}$ or $\mathrm{VC}$ word-order in the Romance languages (4a, 10a and 10b), and for obvious syntactical reasons the subjects are excluded from the sentences.

25 R. Posner, op. cit., p. 167.

26 Ibid. 
(10a) ¡Ábrela! (S)

(10b) Deschide-o! (R)

Clitic doubling is frequent in colloquial Romance languages, and has a topicalizational function. As has been shown earlier this anaphoric process lifts out one element of the standard composition of the phrase, and that element must be substituted by a clitic (11a and 11b).

(11a) La novela, Alberto la compró en Diógenes. (S) (cf. ex. 2c!)

(11b) L'esposizione di Paolo, l'ho vista. (I)

This will not be dealt with here, but for two interesting examples. In Romanian dialects (Transylvanian and Moldovan) the clitic can take both the proclitic and the enclitic position (12a). This can also be the case in Friulian (12b). ${ }^{27}$ In non-standard Transylvanian Romanian the auxiliary can be postpositioned and the clitic inserted (12c). This forms a foot, a phonetic group, where the second syllable of the participle carries the stress. ${ }^{28}$ A similar word-order can also be found in Sardinian where the finite verb (podere) is postpositioned (12d). ${ }^{29}$

(12a) $\mathbf{L}$-am va* zutu-l. (R)

(12b) I a dit-i. (Fr)

(12c) $\mathrm{Va}^{\star}$ zutul-am. (R)

(12d) Si jeu facher lu podere, [...]. (Sa)

Similar to the imperative is the Italian deictic adverb ecco which also postpositions the clitic (13a) as does the Portuguese eis/ei (13b). This, as well as the Portuguese tmesis, i.e. the interpolation of the clitics in the future and conditional (13c) as for example Spaniards used to do in the Middle ages (13d), is left out in the following discussion. It should perhaps be stressed that my intention is not to describe all possibilities and regional varieties in all Romance languages but to give a good idea of the complexity as well as general tendencies.

(13a) Eccoci! (I)

(13b) Ei-las! (P)

27 R. Posner, op. cit., p. 169.

28 D. Abercrombie, "Syllable Quantity and Enclitics in English". In D. Abercrombie et al. (eds.), In honour of Daniel Jones. Papers contributed on the occasion of his eighties birthday 12 September 1961, London and Beccles, 1964, pp. 217.

29 P. Bec, Manuel pratique de philologie romane, Paris, 1971, p.289. 
(13c) Di-lo-ei. (P)

(13d) Veerte as con el Çid, el de la barba grant, [...] (S, El Cid 2410)

The negation is put before the clitic(s) in modern Romance languages SnegCV, although this was not always the case in medieval times (14a). Modern Portuguese also accepts clitics positioned before the negation in interrogative sentences and certain subordinated clauses (14b). 30

(14a) Et desque vio que lo non fazía, levantóse muy sañudo de la mesa [...] (S, El Conde Lucanor, enxiemplum XXXV)

(14b) Quem o não quer fazer? (P)

In Italian the proclisis used to be considered elegant in connection with a negation and an infinitive (15a). ${ }^{31}$ Some Romance languages like French and Occitan often add an extra complement (pas or ges etc.) to the negation and this comes directly after the finite verb (15b and 15c). Some Romansh dialects always stick to the postposition, and like English the clitic is positioned after the participle (15d and $15 \mathrm{e})$.

(15a) [...] al pericolo de non ci riuscire [...] (I, Manzoni, I Promessi sposi, VI:34)

(15b) Je ne l'ai pas fait. (F)

(15c) E de cafè, $n$ 'en prenès ges. $(\mathrm{O})$

(15d) Jeu am buca fetg il. (RR)

(15e) I have not done it.

The question is now what happens in more complex sentences where there are at least two verbs of which one is finite and the other one is infinite. Since the verbal syntagm (VP) in these sentences consists of two parts $-\mathrm{V}_{\mathrm{f}}$ (=finite verb) and $\mathrm{V}_{\mathrm{i}}$ (=infinite verb) - the clitics could be attached to any of these two acting verbs had it not been for $V_{f}$ often being an auxiliary verb that does not present any action of its own but merely modifies the message presented in the phrase. It would therefore seem only logical if the clitic kept to the $\mathrm{V}_{\mathrm{i}}$. This is by no means the case. On the contrary the clitic attaches more often to $V_{f}$, as has been suggested earlier.

The notion auxiliary verb is in itself an often discussed and not very well defined category. As H. Kronning points out two main criteria must be fulfilled: it must take an impersonal mode like infinitive, parti-

30 S. Bjellerup, Portugisisk formlära och syntax, Lund, 1973, p. 42.

31 L. Serriani, op. cit., Torino, 1989, p. 259. 
ciple and gerund, and it must have a grammatical signification, i.e. temporal ('have'), aspectual ('go to') or modal ('can'). ${ }^{32}$ That these verbs are truly part of the same VP, is shown by the fact that referentially they constitute one unit and, consequently, an answer can refer to the whole VP by using only the auxiliary without the usage of any clitic (16a-c). If the finite verb is not an auxiliary the presence of a clitic is necessary in the answer, provided this is not just a simple 'yes' or 'no' (16d and $16 \mathrm{e})$.

(16a) ¿Puedes ayudarme? - Sí, puedo. (S)

(16b) Est-ce que tu peux m'aider? - Oui, je peux. (F)

(16c) $\mathrm{Ma}^{\star}$ put3 eti ajuta? - Da, pot. (R)

(16d) Ti hanno pregato di tornare domani? - Si, (mi hanno pregato di questo). (I)

(16e) Piensas en comprarte una casa? - Sí, (lo pienso). (S)

From a strictly formal point of view it is the conjugated finite verb that is the nucleus of the VP, which implies that this is the central part of the message of the VP, and it should be a very natural thing that this fundamental element of the syntagm should be the one to gather other parts of the syntagm like clitics. However, from a semantic point of view the central message lies with the infinitive, i.e. infinite verb. The finite modal (and to a certain extent the aspectual) auxiliary only modifies the emission of a message on a pragmatic level. It does not change the essence of the message but the way this is presented.

In phrases with an auxiliary and an infinite verb form there are four possible positions for the clitic: $\mathrm{SCV}_{\mathrm{f}} \mathrm{V}_{\mathrm{i}}, \mathrm{SV}_{\mathrm{f}}+\mathrm{C} \mathrm{V}_{\mathrm{i}}, \mathrm{SV}_{\mathrm{f}} \mathrm{CV}_{\mathrm{i}}$ and $\mathrm{SV}_{\mathrm{f}}$ $\mathrm{V}_{\mathrm{i}} \mathrm{C}(17 \mathrm{a}-\mathrm{d})$. As we have seen in (12c) and (12d) there also exists the marginal possibility of a $\mathrm{V}_{\mathrm{i}}+\mathrm{C}(+) \mathrm{V}_{\mathrm{f}}$ order, but this is more surprising from a verb order point of view. The position of the clitic is actually the same as in $\mathrm{SV}_{\mathrm{f}} \mathrm{V}_{\mathrm{i}} \mathrm{C}$.

The space between two of the letters in the latter combinations is there to point out which verb is attracting the clitic, when this is inserted between the two verbs. The + is to describe the position of an enclitic pronoun like in (17b). In the Romanian case the infinite constructions

32 H. Kronning, Modalité, cognition et polysémie: sémantique du verbe modale devoir, Uppsala, 1996 p. 59. 
are rare $^{33}$, and mostly substituted by an infinitive like in many other languages that belong to the Balkan "Sprachbund" (17e). Certain verbs like putea, 3tie, etc. ${ }^{34}$, may still use the infinitive that exists, although it is seldom used $(16 \mathrm{c})$, since the subordination is predominant.

(17a) La quiero cantar. (S)

(17b) Violos el rey, fermoso sonrrisava [...]. (S, El Cantar de mio Cid, verso 873)

(17c) Je veux la chanter. (F)

(17d) Voglio cantarla. (I)

(17e) Vreau sa ${ }^{\star}-\mathrm{I}$ cânt. (R)

In French the word-order is now fixed $\mathrm{SV}_{\mathrm{f}} \mathrm{CV}_{\mathrm{i}}$ (18a), although the proclitic position was preferred in old French (18b) and existed as a possibility in the 17 th century $(18 \mathrm{c}) .{ }^{35}$ That both existed at the same time is clear from the example where both positions are included in the very same proposition. Although Sardinian can insert the clitic between the verbs (12d), the proclitic position also exists (18d).

(18a) Je devais bien le faire. (F)

(18b) Je le devoie bien fere. (F, Queste 11,15)

(18c) Vous l'osâtes bannir, vous n'osez l'éviter. (F, Racine, Phèdre v. 764)

(18d) Si eu lu potere fagher, [...]. (Sa, cf. 12d). ${ }^{36}$

In other Romance languages the $\mathrm{SCV}_{\mathrm{f}} \mathrm{V}_{\mathrm{i}}$ (and $\mathrm{SV}_{\mathrm{f}}+\mathrm{C} \mathrm{V}_{\mathrm{i}}$ in the Portuguese, Galician and Asturian cases) and $\mathrm{SV}_{\mathrm{f}} \mathrm{V}_{\mathrm{i}} \mathrm{C}$ coexist. Albeit the latter has been promoted, the modern tendency is that the clitic precedes the finite verb. ${ }^{37}$ The SOV order is thus practically the only basic order in Romance languages when the object is a clitic, with the already mentioned Portuguese exception $\mathrm{SV}_{\mathrm{f}}+\mathrm{C}$. Sursilvan and colloquial Brazilian Portuguese are disregarded since they do not use clitics. It seems that $\mathrm{SOV}$ is becoming the predominant word-order in phrases

33 A. Beyrer, K. Bochmann \& S. Bronsert, Grammatik der rumänischen Sprache der Gegenwart, Leipzig, 1987, p. 15.

34 A. Beyrer, K. Bochmann \& S. Bronsert, op. cit. p. 178. K. Sandfeld Jensen, Rumaenske Studier 1, Lund, 1900.

35 K. Togeby, Précis historique de grammaire française, Copenhagen, 1975, p. 117

36 There is no misprint in the two Sardinian examples. Both $e u$ and jeu exist in diferent subdialects.

37 R. Posner, op. cit., p. 167. 


\section{4}

with two verbs. Thus the general SVO system is out-ruled by what is the standard word-order in constructions with clitics, SOV. In phrases where there are two verb forms there is a vacillation between the two systems.

As has been shown French was to develop a $\mathrm{SV}_{\mathrm{f}} \mathrm{CV}_{\mathrm{i}}$ system, but there is an exception where the $\mathrm{SCV}_{\mathrm{f}} \mathrm{V}_{\mathrm{i}}$ is still applied (20f and 21a). Infinitive is very rare in Romanian and only appears after a very limited number of verbs, which means that the SCV stays valid, although it is extended to $\mathrm{SV}_{\mathrm{f}} \mathrm{Q}$, where $\mathrm{Q}=$ conjunction $\left(\mathrm{sa} / \mathrm{ca} \mathrm{c}^{\star}\right)+\mathrm{CV}_{\mathrm{f}} \cdot(19 \mathrm{a}$; cf. $19 \mathrm{~b}$ with $\mathrm{SV}_{\mathrm{f}} \mathrm{V}_{\mathrm{i}} \mathrm{C}$ and $19 \mathrm{c} \mathrm{SCV}_{\mathrm{f}} \mathrm{V}_{\mathrm{i}}$ ). In the Standard Romanian construction there are two finite verbs which differentiate it from all other Romance languages in sentences where the two verbs take the same subject.

(19a) Ana vrea sa ${ }^{\star}$ o cânt. (R)

(19b) Anna vuole cantarla. (I)

(19c) Anna la vuole cantare. (I)

The competition between the structurally fundamental SVO order and the SCV order that could be seen as a remnant from an older Latin system - SOV, has its consequences in sentences with two verbs, since this opens the three possibilities $\mathrm{SCV}_{\mathrm{f}} \mathrm{V}_{\mathrm{i}}$ (20a and 20b), $\mathrm{SV}_{\mathrm{f}} \mathrm{CV}_{\mathrm{i}}$ (20c) and $\mathrm{SV}_{\mathrm{f}} \mathrm{V}_{\mathrm{i}} \mathrm{C}(20 \mathrm{~d}$ and $20 \mathrm{e})$. Only French can take the second order, and this is now the standard French order. Nevertheless, the first order is compulsory in combinations with certain verbs (20f-h). ${ }^{38}$ Posner maintains that modal verbs have a preference for climbing, and this seems to be the case, although it is still only a preference. 39

(20a) Lo quiero hacer. (S)

(20b) Ho vull fer. (C)

(20c) Je veux le faire. $(\mathrm{F})$

(20d) Voglio farlo. (I)

(20e) Quero dizê-lo. (P)

(20f) Je le fais entrer. $(F)$

(20g) El vaig veure venir. (C)

(20h) Le vi venir. (S)

38 See the discussion further on.

39 Posner, op. cit., p. 264. 
I will argue that since the SCV order has come to be the rule in most Romance languages this tends to prevail over the basic SVO order in $\mathrm{SV}_{\mathrm{f}} \mathrm{V}_{\mathrm{i}}$ phrases. That this is the case is motivated by the fact that in constructions where there is an option: both $\mathrm{SCV}_{\mathrm{f}} \mathrm{V}_{\mathrm{i}}{ }^{40}$ and $\mathrm{SV}_{\mathrm{f}} \mathrm{V}_{\mathrm{i}} \mathrm{C}$ are possible, but when only one word-order is possible it is almost always $\mathrm{SV}_{\mathrm{f}} \mathrm{V}_{\mathrm{i}} \mathrm{C}$ that is excluded. This means that the clitic microsystem, SCV surpasses the general SVO order. In the spoken languages this tendency seems to be growing ${ }^{41}$. French is the obvious exception, but historically, $\mathrm{SCV}_{\mathrm{f}} \mathrm{V}_{\mathrm{i}}$ is also valid for French. In modern French $\mathrm{SV}_{\mathrm{f}}$ $\mathrm{CV}_{\mathrm{i}}$ is the generalised standard. Yet the $\mathrm{SCV}_{\mathrm{f}} \mathrm{V}_{\mathrm{i}}$ is still required in some constructions, and these coincide with the cases in other Romance languages where $\mathrm{SCV}_{\mathrm{f}} \mathrm{V}_{\mathrm{i}}$ is obligatory.

As we have seen the auxiliary is defined as a verb that must be constructed with an impersonal mode (infinitive, past participle or present participle), and it must have a grammatical significance. ${ }^{42}$ When this is not the case the two verbs do not constitute one single verbal action but two. However, in both cases we are dealing with what is traditionally described as accusative with infinitive (Accusativus cum infinitivo). The original meaning is final although this has been weakened.

"In dem Satz doceo te sapere kann der Inf. Sowohl von seiner urspr. finalen Bedeutung her verstanden werden (,ich unterrichte dich zum Weisesein, damit du weise wirst") auch als Stellvertretener eines Sachobjekts ohne finalen Nebensinn neben dem persöhnlichen Objekt te wie in doceo te sapientiam (,ich lehre dich Weisheit"). Keine finale Auffassung des Infinitivs ist dagegen mehr möglich bei einem untergeordneten Verbum der Wahrnehmung wie video te venire, wo der Inf. zwar auch ein Sachobjekt vertritt, [...] Ganz eng schliesslich wird die Einheit, zu der Akk. und Inf. sich verbinden, wenn keiner von beiden mehr für sich als Objekt von dem überordneten Verbum abhängig gedacht werden kann [...] Je mehr nun Inf. und Akk. sich aus der Beziehung als selbständiges Objekt zum übergeordneten Verbum lösen und zusammenwachsen, desto leichter können sie gleichsam wie Prädikat und Subjekt eines entsprechenden Nebensatz escheinen:"43

The origin of this construction in Latin referred to full verbs and not to auxiliaries. The same goes for causative Verbs in Latin ${ }^{44}$. N.B. the (S)

$\overline{40} \mathrm{The}_{\mathrm{SV}}+\mathrm{C} \mathrm{V}_{\mathrm{i}}$ order is here regarded as a variety of $\mathrm{SCV}_{\mathrm{f}} \mathrm{V}_{\mathrm{i}}$. as it does not change the argument of this article.

41 M. Casado, El castellano actual: usos y normas, 2nd ed. Pamplona, 1991, p.68.

42 H.Kronning, op. cit., p. 59.

43 H. Rubenhauer and J.B. Hofmann, op. cit., p. 192.

44 Ibid. 
$\mathrm{V}_{\mathrm{f}} \mathrm{CV}_{\mathrm{i}}$ order in the examples in the quotation corresponds perfectly to modern French.

Although there is a clause union between the two verbs that makes them a syntactic unit, there is a constructional difference between two full verbs (I) on one hand and an auxiliary + a full verb (II) on the other. Syntagmatically the predicate consists of two verbal actions (VP) that are interdependent in the first case, while in the second case the auxiliary does not express a verbal action of its own and depends on the full verb. This difference could be described in the following way:

I)

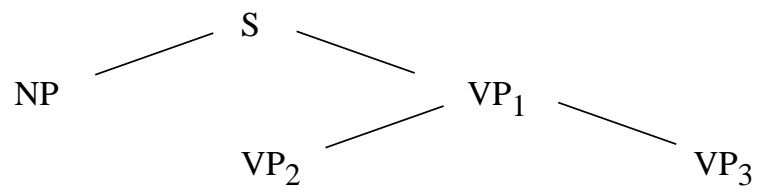

II)

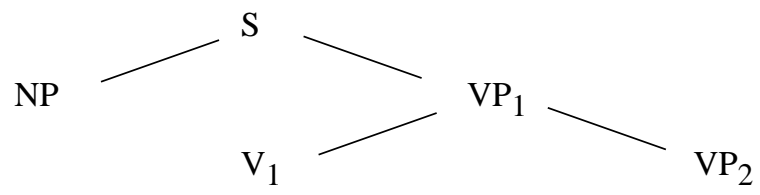

The concept of modal auxiliaries is fairly controversial and it could be argued that they should be included in category I. However, in combination with clitics they behave in a way that suggests their being considered parts of the same category as other auxiliaries, i.e. category II.

Causative or operator verbs, do and let, are more restricted in their usage then most verbs. In French the norm is $\mathrm{SCV}_{\mathrm{f}} \mathrm{V}_{\mathrm{i}}(21 \mathrm{a})$, while the standard order is $\mathrm{SV}_{\mathrm{f}} \mathrm{CV}_{\mathrm{i}}$ as we have seen (21b). ${ }^{45}$ Nevertheless, the most frequently used construction is splitting the two clitics $\mathrm{SCV}_{\mathrm{f}} \mathrm{V}_{\mathrm{i}} \mathrm{C}$ (24c). Other romance languages seem to exclude $\mathrm{SV}_{\mathrm{f}} \mathrm{V}_{\mathrm{i}} \mathrm{C}$ or at least avoid it in conection with causative verbs (21c-21e). ${ }^{46}$ The $\mathrm{V}_{\mathrm{i}}$ enclisis is not accepted by native speakers when I have presented them all possibililities (21f and $21 \mathrm{~g}$ ).

(21a) Je te le laisse faire. (F, colloquial cf. 24c)

(21b) Je vais le faire. (F)

45 G. Boysen, Fransk grammatik, Lund, 1996, pp. 200-201.

46 C. Schwarze, op. cit., p.242. 
(21c) Te lo lascio fare. (I)

(21d) Te lo dejo hacer. (S)

(21e) T'ho deixo fer. (C)

(21f) *Lascio fartelo. (I)

(21g) *Dejo hacértelo. (S)

There is mostly a choice between an infinitive and a subordinate clause after a causative verb. However, this choice is semantic and when the meaning is 'make'/' do' the infinitive is often compulsory (22a), but when the meaning is 'see to'/'take care of' the subordinate clause is the first choice (22b), and (22c) is regarded incorrect. 47

(22a) Esta lluvia hace crecer las plantas. (S)

(22b) Fai che il nonno si alzi alle otto. (I)

(22c) *Fai alzarsi il nonno alle otto. (I)

In these sentences there often exists a possibility of separating the two clitics. The general principle of always keeping the clitics together (23a and $23 b$ ) can thus be violated for semantic reasons (23c).

(23a) Se lo puedo decir. (S)

(23a) Posso dirglielo. (I)

(23c) Et deixo fer-ho. (C)

Example (23c) shows that different subjects can make the clitics attach to both verbs. This is partly due to a close semantic relation between the clitic and the verb. In these sentences one clitic is object to $\mathrm{V}_{\mathrm{f}}$ and subject to $\mathrm{V}_{\mathrm{i}}$ and the other object to $\mathrm{V}_{\mathrm{i}}(24 \mathrm{a}-24 \mathrm{e})$. In these sentences the $V_{f}$ is either a causative or a perception verb. ${ }^{48}$ This is not the case when $\mathrm{V}_{\mathrm{f}}$ is an auxiliary. If the two verbs take different subjects the $\mathrm{V}_{\mathrm{i}}$ has to be turned into a subordinate clause ( $24 \mathrm{f}$ and $24 \mathrm{~g}$ ). Sentences like ( $24 \mathrm{~h}$ and 24i) are simply not used.

(24a) Te dejo hacerlo. (S)

(24b) Ti lascio farlo. (I, hardly ever used)

(24c) Je te laisse le faire. (F)

(24d) Je les vois très bien le faire. (F)

47 C. Schwarze, op. cit., p. 415.

48 K.J. Danell, Remarques sur la construction dite causative, Acta Universitatis Stockholmiensis, Romanica Stockholmiensia, 9, Stockholm, 1979, p. 45. 
(24e) Les veo hacerlo. (S)

(24f) Je veux que tu le lises. (F)

(24g) Quiero que lo leas. (S)

(24h) *Je te le veux lire. $(\mathrm{F})$

(24i) *Te lo quiero leer. $(\mathrm{S})^{49}$

As R. Posner has pointed out climbing is the rule in most Romance languages in sentences with a causative or perception verb $(25 \mathrm{a}-25 \mathrm{~g}) .50$ Often there is a slightly different meaning in the varities ${ }^{51}$ : the proclisis meaning "I made him do it" and the enclisis "I made it done for him". Romance perception verbs seem to exclude the enclisis, while it still remains an option in sentences with a finite causative verb. However, this is not the case with causatives in Italian (25c and 25d). ${ }^{52}$ Only the proclitic $\mathrm{SCV}_{\mathrm{f}} \mathrm{V}_{\mathrm{i}}$ is accepted by speakers, although a second clitic can be attached to the $V_{i}$ as we have seen above (24b). When the subjects are different, several Romance languages can use either infinitive or gerund/present participle for the infinite verb form after perception verbs $(25 \mathrm{e}-25 \mathrm{j})$, while causative verbs seem to impose the usage of an infinitive (or a subordinate clause). In these cases the proclitic position is still often possible (25a and 25b).

(25a) Se lo hice hacer./Hice hacérselo. (S)

(25b Li ho vaig fer fer./Vaig fer-li-ho. ${ }^{53}(\mathrm{C})$

(25c) Glielo farò fare. (I)

(25d) *Farò farglielo. (I)

(25e) Le ví venir./Le ví viniendo. (S)

(25f) El vaig veure venir./El vaig veure venint. (C)

(25g) L'ho visto venire./L'ho visto venente. (I)

(25h) îl va* $\mathrm{d}$ venind./Va* $\mathrm{d}$ venindu-l./ Va* $\mathrm{d}$ sa* vina* . (R)

49 The sentence is unacceptable if the intended meaning is "I want to make you read it" but perfectly correct if the meaning is "I want to read it to you".

50 R. Posner, op. cit., p. 264.

51 See footnote 49.

52 Schwarze, op. cit., p. 193.

53 In Catalan the verb anar + infinitive is a periphrastic preterite, while anar $+a+$ infinitive is a periphrastic future like in French (aller + inf.) and Spanish (ir $a+$ inf.). Cf. A. M. Badía Margarit, Gramatica catalana, vol. I, Madrid, 1985 (1962), pp. 276277. 
(25i) Vejo-o vir. (P)

(25j) Je l'ai vu venir./ Je l'ai vu venant. (F)

To this category also belong verbs for 'know' and 'can' in their auxiliary meaning and function (26a-g). In these cases there is always a coreference between the subject (formally expressed or not) of the infinitive and one of the arguments, i.e. subject or object, of the finite matrixverb.

These verbs are, as we have seen, among the few Romanian verbs that can actually be combined with infinitives (26d). In Italian sapere (and volere) mostly go with enclisis (cf. 19b and 20d) while potere and dovere have clitics in the proclitic position (25c). ${ }^{54}$

In Portuguese there is a clear difference between European and Brazilian usage. In the latter case there is normally a $\mathrm{SV}_{\mathrm{f}} \mathrm{CV}_{\mathrm{i}}$ order (26e), while the former takes either $\mathrm{SV}_{\mathrm{f}}+\mathrm{C} \mathrm{V} \mathrm{V}_{\mathrm{i}}$ or $\mathrm{SV}_{\mathrm{f}} \mathrm{V}_{\mathrm{i}} \mathrm{C}(26 \mathrm{f})$. The proclisis is evidently favoured also in less well-known Romance languages like Dalmatian (26g).

(26a) Elle sait la chanter. (F)

(26b) Sa cantarla/La sa cantare. (I)

(26c) Sabe cantarla/La sabe cantar. (S)

(26d) îl ştie cânta/Ştie sa * -l cânte. (R)

(26e) Pode me dizer? (P)

(26f) Pode-me dizer?/Pode dizer-me? (P)

(26g) Yu non lo potaja lasur a skol. (D) ${ }^{55}$

There are, of course, other kinds of full verbs that are attached to an infinitive with or without a preposition. The evidence points to a hierarchy of preference for climbing among verbs that take the infinitive, with modals and aspect auxiliaries high on the list, followed by conative (e.g. 'try') (27a, 27b and 27h), motion (e.g. 'come') (27c, 27f and $27 \mathrm{~g}$ ) and raising (e.g. 'seem') verbs (27d). ${ }^{56}$ In French the gérondif is a separate case (27e). However, it is hard to find good examples of motion verbs in a concrete sense that take an infinitive, since they mostly

54 G. Skytte, La sintassi dell'infinitivo in italiano moderno, Supplement to Revue Romane, vol. 27, 1983, pp. 93-94.

55 P. Bec, op. cit., p. 415.

56 Posner, op. cit., p.265. 
take a gerund indicating a simultanous action ( $27 \mathrm{f}$ and $27 \mathrm{~g}$ ). It is also possible that the presence of a preposition and adverbs between the finite and the infinite verb forms promotes the enclisis if the clitic is semantically closely related to the verb (27h and 27i).

(27a) Lo intento hacer/Intento hacerlo. (S)

(27b) Lo trato de hacer/Trato de hacerlo. (S)

(27c) Mi viene da piangere. (I)

(27d) Sentín tanta fame que semellaba írenseme fura-las tripas. (G)

(27e) Il vient en la sifflant. (F)

(27f) Passò senza salutarmi. (I)

(27g) M-a venit idea asta* scriind. (R)

(27h) J'essais de le faire. (F)

(27i) Hacen bien en hacerse triunfalistas. (S, El Mundo, p.10, 7/5 -97)

In periphrastic constructions with a finite verb that takes a present participle or gerund there does not seem to be any main differences from finite verbs followed by infinitives. The same tendencies apply, i.e. the verb categories already discussed that favour enclisis or proclisis do this when followed by a present participle/gerund as well (28a-d).

(28a) Ho estic fent/Estic fent-ho. (C)

(28b) Lo sigo escribiendo/Sigo escribiéndolo. (S)

(28c) Le istituzioni si venivano orientando in senso più democratico.

(28d) Une difficulté pouvant se résoudre. (F)

When the participle em introduces the clause in Portuguese the clitic must be proclitically attached to the gerund (29a). ${ }^{57}$ The French gérondif order remains fixed (27e and 29b). Also in Romansh (Engadine) there is a construction similar to the French gérondif, and the wordorder correspond to the French one, i.e. in+/C/+gerund (29c). 58

(29a) Em me vendo, voltou. (P)

(29b) Tout en les détestant, il enviait les Italiens. (F, Beauvoir, Mémoires, p. 264)

(29c) El la consolaiva in la charezzand. (RR, eng.)

57 S. Bjellerup, op. cit., p. 40.

58 G.P. Ganzoni, op. cit., p. 176. 
There also exists the possibility to expand the VP to two (or perhaps even more) infinite verb forms $\mathrm{SV}_{\mathrm{f}} \mathrm{V}_{\mathrm{i}} \mathrm{V}_{\mathrm{i}}$. In this case the clitic could be linked to any of the three verb forms. However, it seems that the same tendencies, discussed earlier, apply to these clauses as well (30ac).

(30a) Ho intentato farli capire. (I)

(30b) Cualquier otra necesidad que tengas, no dudes en hacérnosla saber. (S)

(30c) Il essait de continuer à le faire, $(\mathrm{F})$

Infinitives have come to be used a lot more in Romance languages than they were in Latin. As a consequence of this increased usage new syntactical structures have arisen. The problem that concerns us in this article is the location of clitics in sentences with two verbs of which one is finite and one if infinite. As we have seen there exist four possibilities: $\mathrm{SCV}_{\mathrm{f}} \mathrm{V}_{\mathrm{i}}, \mathrm{SV}_{\mathrm{f}}+\mathrm{C} \mathrm{V}_{\mathrm{i}}, \mathrm{SV}_{\mathrm{f}} \mathrm{CV}_{\mathrm{i}}$ and $\mathrm{SV}_{\mathrm{f}} \mathrm{V}_{\mathrm{i}} \mathrm{C}$. The latter two correspond to the ruling word-order in Romance languages SVO, while the first reflects the SOV order (and so does the second). However, clitics preserve this latter word-order in all Romance languages with the exception of some Romansh dialects. Where there are two verbs, clitics can take either position. Nevertheless, the presumed free choice between these options turns out to be much more restricted than is generally held to exist between the proclisis and the enclisis. Causative and perception verbs all tend to favour the proclitic word-order, to the degree that this is not only preferred but in some languages the only possible one. In the spoken language this proclitic tendency is strong and spreading. The usage of certain verbs and syntactically interpolated elements like prepositions and adverbials must be considered in every single case, since these might have an influence on each occurrence, but this does not obscure the general view that the SCV order is favoured. We could thus conclude that although clitics are used both enclitically and proclitically in a fairly complex way, the SCV order is the dominant word-order in Romance languages also in sentences with two verbs of which one is finite and one infinite.

\section{Bibliography}

Abercrombie, D. (1964): Syllable Quantity and Enclitics in English. In: D. Abercrombie et al. (eds.): In honour of Daniel Jones. Papers contributed on the occasion of his eighties birthday 12 September 1961. London and Beccles. 


\section{2}

Alarcos Llorach, E. (1994): Gramática de la lengua española. Madrid

Alvarez, R., X.L. Regueira \& H. Monteagudo (1986): Gramática Galega. Vigo.

Badía Margarit, A.M. (1985 (1962)): Gramática catalana, vol. I. Madrid.

Bec, P. (1971): Manuel pratique de philologie romane. Paris.

Beyrer, A., K. Bochmann and S. Bronsert (1987): Grammatik der rumänischen Sprache der Gegenwart. Leipzig.

Bjellerup, S. (1973): Portugisisk formlära och syntax. Lund.

Boysen, G. (1996): Fransk grammatik. Lund.

Casado, M. (1991): El castellano actual: usos y normas, 2nd ed. Pamplona.

D’Andrés Díaz, R. (1993): Allugamientu de los pronomes átonos col verbu n'asturianu. Oviedo.

Danell, K.J. (1979): Remarques sur la construction dite causative. In: Acta Universitatis Stockholmiensis, Romanica Stockholmiensia, 9. Stockholm.

Fant, L. (1985): El pronombre clítico en las lenguas iberorománicas y en otros idiomas. Aspectos sobre una cuestión de tipología lingüística. In: CEBAL 7. Copenhagen.

Ganzoni, G.P. (1983): Grammatica ladina. Samedan.

Greenberg, J.H. (1966): Some universals of grammar with particular reference to the order of meaningful elements. In: Universals of Language, ed. by J.H. Greenberg. Cambridge: MA.

Hawkins, J.A. (1983): Word-order Universals. New York: Academic Press.

Hawkins, J.A. (1990): Seeking Motives for Change. In: W. Croft, K. Denning and S. Kremmer (eds.): Studies in Typology and Diachrony: For Joseph H. Greenberg. Amsterdam/Philadelphia: John Benjamin Publishing Company.

Ineichen, G. (1991): Allgemeine Sprachtypologie. Darmstadt.

Kayne, R. (1975): French Syntax: The Transformational Cycle. Cambridge: MA.

Krenn, H. and M.A. Soares de Carvalho Mendes (1987): Modernes Portugiesisch. Tübingen.

Kronning, H. (1996): Modalité, cognition et polysémie: sémantique du verbe modal devoir. Uppsala.

Lehman, W.P. (1974): Proto-Indo-European Syntax. Austin: University of Texas Press.

Libro Sacramental Parroquia de Santa María de Mayor (1547). Alcalá de Henares.

Posner, R. (1996): The Romance Languages. Cambridge: Cambridge University Press.

Rubenbauer, H. and J.B.Hofmann (1995): Lateinische Grammatik. neubearbeitet von R. Heine. München: Bamberg.

Sandfeld Jensen, K. (1900): Rumaenske Studier 1. Lund.

Sapir, E. (1921): Language. An Introduction to the Study of Speech. New York.

Schwarze, C. (1995): Grammatik der italienischen Sprache, 2nd ed. Tübingen.

Serriani, L. (1989): Grammatica italiana, Italiano comune e lingua letteraria. Torino. 
Skytte, G. (1983): La sintassi dell'infinitivo in italiano moderno. Supplement to Revue Romane, vol. 27. Copenhagen.

Spescha, A. (1989): Grammatica sursilvana. Chur.

Söhrman, I. (1995): Deutsche Einflüsse auf das Rätoromanische. In: M. Todtenhaupt \& I. Valfridsson, Sprache als lebendige Kulturspiegel, Acta Universitatis Umensis. Umeå Studies in Humanities 119. Umeå.

Togeby, K. (1975): Précis historique de grammaire française. Copenhague.

E. Torrego, (1995): From argumental to non-argumental pronouns: Spanish doubled reflexives. In: Probus 7.

Thöni, G.P. (1969): Rumantsch surmeir. Chur.

Vaquero de Ramírez, M. (1996): El español de América, II, Morfosintaxis y Léxico. Madrid. 
